\title{
Study of a Novel Vertical Flow Constructed Wetland System with Drop Aeration for Rural Wastewater Treatment
}

\author{
Juan Zou • Xuesong Guo • Yunping Han • \\ Junxin Liu $\cdot$ Hanwen Liang
}

Received: 11 May 2011/Accepted: 3 August 2011 /Published online: 18 August 2011

(C) Springer Science+Business Media B.V. 2011

\begin{abstract}
Constructed wetlands are recognized as a reliable technology for rural wastewater treatment. However, conventional constructed wetlands face problems with low pollutant removal efficiency and limited oxygen transfer capability. Therefore, a novel vertical flow constructed wetland (VFCW) system with drop aeration was developed in this study. Two pilot-scale vertical flow constructed wetlands of $0.75 \mathrm{~m}^{2}$ each were constructed with the same dimensions and configuration but different media, one of which (named as $\mathrm{CW}_{1}$ ) was filled with a 1:1 mixture (by weight) of zeolite and dolomite and the other (named as $\mathrm{CW}_{2}$ ) with the same zeolite only. The oxygen transfer capability of a multilevel two-layer drop aeration device, organics and nitrogen removal of $\mathrm{CW}_{1}$ and $\mathrm{CW}_{2}$, and pollutant distribution along the depths of $\mathrm{CW}_{1}$ and $\mathrm{CW}_{2}$ in different operational phases were studied. The results demonstrated that compared with the direct drop aeration process, the multilevel, two-layer drop aeration device supplied 2$6 \mathrm{mg} / \mathrm{L}$ higher dissolved oxygen per meter of drop height, and after installation of the six-level, two-layer drop aeration devices, the 5-day biochemical oxygen demand removal load was improved from 8.1 to $14.2 \mathrm{~g} \mathrm{~m}^{-2}$ day $^{-1}$ for $\mathrm{CW}_{1}$. With regard to the different
\end{abstract}

J. Zou $\cdot$ X. Guo $\cdot$ Y. Han $\cdot$ J. Liu $(\bowtie) \cdot$ H. Liang

Research Center for Eco-Environmental Sciences, Chinese

Academy of Sciences,

Beijing 100085, China

e-mail: jxliu@rcees.ac.cn filter media, nitrogen removal was improved by the adsorption of zeolite in the first year, with 5-36\% higher $\mathrm{NH}_{4}{ }^{+}-\mathrm{N}$ removal efficiency of $\mathrm{CW}_{2}$ compared with that in $\mathrm{CW}_{1}$. Since it did not have a significant positive effect on phosphate removal, dolomite can be replaced by zeolite. The chemical oxygen demand removal mainly took place in the upper $15-\mathrm{cm}$ filter layer in different operational phases, while nitrogen distribution along the depths of the VFCWs was different in different operational phases. In addition, as no operational problems occurred, the vertical flow constructed wetland system with drop aeration is an appropriate alternative for rural wastewater treatment, with numerous advantages of low capital and operation costs, no energy consumption, easy maintenance, high hydraulic loading rate, high pollutant removal efficiency, and no clogging.

Keywords Rural wastewater treatment . Vertical flow constructed wetlands · Drop aeration · Zeolite .

Dolomite

\section{Introduction}

Increasing attention is being paid to researches on the improvement of the effluent quality of wastewater treatment in rural areas to protect the receiving waters nearby. Researches on appropriate technologies for wastewater treatment in rural areas are becoming more and more important in Europe due to the implementa- 
tion of the Urban Wastewater Directive, which forces the small communities below 2,000 equivalent inhabitants to treat their wastewater (Martin et al. 2007). Denmark has adopted national regulations to define the permissible discharge of organics and nutrients from the properties in rural areas (Brix and Arias 2005).

Nowadays, water pollution in rural areas of China is increasingly serious because there are about $96 \%$ villages which discharge their untreated wastewater directly to the receiving waters (MHURDPRC 2005). To protect lakes, rivers, and other water bodies from pollution, the Chinese government has established corresponding laws, regulations, and criteria (Liang et al. 2010). At present, major attention has been attached to wastewater treatment and disposal in rural areas of China. However, as villages lack economic resources and trained personnel, the alternative wastewater treatment systems are developed and promoted with low costs, energy saving, and simpler operation (Cameron et al. 2003), of which the constructed wetlands (CWs) may be a valid alternative for purifying rural wastewater and are growing in popularity on a global basis as a secondary and tertiary treatment for domestic wastewater (Arroyo et al. 2010; Babatunde et al. 2008; Coleman et al. 2001; Cooper 2009; Steer et al. 2002).

Constructed wetlands can be subdivided into two main categories: horizontal flow (HF) and vertical flow (VF) systems. Compared with the horizontal flow system, vertical flow constructed wetlands (VFCWs) have smaller area demand, higher oxygen transfer capability, and simple hydraulics (Cooper 2009; Luederitz et al. 2001). However, conventional VFCWs have basic disadvantages such as low hydraulic and organics loading rates, easy clogging, and low dissolved oxygen (DO) concentration. The recommended hydraulic and organics loading rates of VFCWs are only $0.05-0.06 \mathrm{~m}^{3} \mathrm{~m}^{-2}$ day $^{-1}$ and $0.01-0.04 \mathrm{~kg} \mathrm{BOD}_{5}$ $\mathrm{m}^{-2}$ day $^{-1}$, respectively (Prochaska et al. 2007). Filter media clogging caused by particulate solid accumulation and biofilm growth is the operational problem that CWs often encounter (Hua et al. 2010; Zhao et al. 2009). Therefore, in order to avoid an anticipated clogging of constructed wetlands, it is recommended that the sewage should be pretreated by physicochemical methods prior to discharge into the vertical flow wetlands (Joan et al. 2007; Prochaska et al. 2007).

The limited oxygen transfer capability of wetlands has led to the development of enhanced treatment systems which are capable of providing sufficient oxygen transfer for the removal of organic material and nitrification of ammonia, introducing oxygen to the system through frequent water level fluctuation (tidal flow; Austin et al. 2003; Behrends et al. 1996), passive air pumps (vertical flow; Green et al. 1998), or direct mechanical aeration of the water in the gravel bed (horizontal flow; Dufay 2000; Flowers 2002; Wallace et al. 2001).

In this study, two pilot-scale vertical flow constructed wetlands of $0.75 \mathrm{~m}^{2}$ each were set up to determine the efficiency of this system in reducing the polluting loads. The oxygen of the VFCWs was supplied by patented multilevel, two-layer drop aeration devices (Liu et al. 2010). Zeolite and dolomite were adopted as the filtering media of the VFCWs, aiming to improve nitrogen removal and to avoid clogging. The oxygen transfer capability of the multilevel, two-layer drop aeration device, organics removal by the VFCWs before and after installation of the multilevel, two-layer drop aeration devices, nitrogen removal by the VFCWs in different operational phases, and the pollutant distribution at different depths of the VFCWs were studied.

\section{Materials and Methods}

\subsection{Description of the Multilevel, Two-Layer Drop Aeration Device}

The direct drop aeration process and the patented multilevel, two-layer drop aeration device are shown in Fig. 1 (six basins were involved in the case of this study). The multilevel, two-layer drop aeration device was composed of six two-layer drop aeration units. The cross-section of the inclined two-layer drop aeration unit was triangular and parallel to each other with a distance of $0.3 \mathrm{~m}$ vertically. The anaerobic influent was controlled by a flow meter, flowed from the sealed chamber, and then fell into the direct drop aeration container or the two-layer drop aeration units. DO in the wastewater of both the direct drop aeration container and the two-layer drop aeration units had been measured at heights of $0.3,0.6,0.9,1.2,1.5$, and $1.8 \mathrm{~m}$.

\subsection{Filtering Materials}

The following materials were selected as filter media of the studied VFCWs: 
Fig. 1 Layout of the direct drop aeration process (a) and the patented multilevel, two-layer drop aeration device (b). 1 Sealed chamber; 2 Flow meter; 3 Direct drop aeration container; 4 Twolayer drop aeration unit

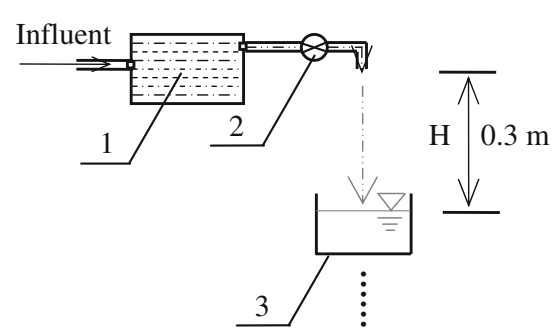

(a)

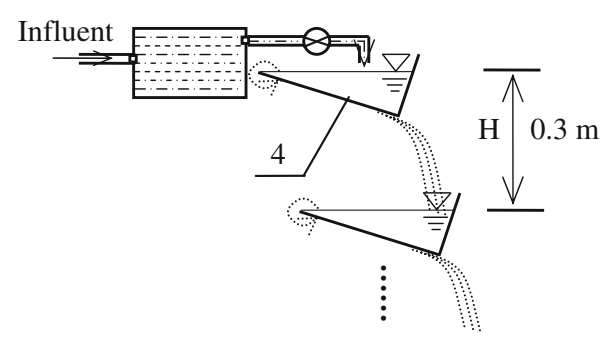

(b)
Zeolite-with diameter $4-8 \mathrm{~mm}$, porosity $35 \%$, bulk density $1.10 \mathrm{t} / \mathrm{m}^{3}$, surface area $10.58 \mathrm{~m}^{2} / \mathrm{g}$, pore diameter $5.62 \mathrm{~nm}, \mathrm{pH} 7.03$, and conductivity $52.0 \mu \mathrm{s} / \mathrm{cm}$ - was composed of $38 \%$ quartz, 33\% clinoptilolite, $6 \%$ analcime, $15 \%$ sanidine, and $8 \%$ illite. It was obtained from GONGYI HUALONG Filter Factory, located in Henan province, China. Pre-experimental data of ammonium adsorption have shown that zeolite has a maximum adsorption capacity of $8.1 \mathrm{mg} \mathrm{NH}_{4}{ }^{+}-\mathrm{N} / \mathrm{g}$.

Dolomite-with diameter $4-8 \mathrm{~mm}$, porosity $35 \%$, bulk density $1.46 \mathrm{t} / \mathrm{m}^{3}$, surface area

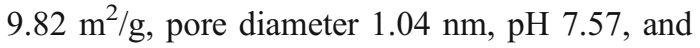
conductivity $33.3 \mu \mathrm{s} / \mathrm{cm}$ - was composed of $100 \%$ dolomite $\left(\left(\mathrm{CO}_{3}\right)_{2}\right) \mathrm{CaMg}$. It was also obtained from GONGYI HUALONG Filter Factory. Pre-experimental data of ammonium adsorption have shown that dolomite has almost no adsorption to ammonium.

Gravel is a naturally occurring silicate mineral containing small amounts of ferric oxide $\left(\mathrm{Fe}_{2} \mathrm{O}_{3}\right)$, aluminum, and calcium oxides. The gravel had a diameter of 6-25 $\mathrm{mm}$ and a bulk density of $1.75 \mathrm{t} / \mathrm{m}^{3}$.

\subsection{Description of the Vertical Flow Constructed Wetlands}

A novel vertical flow constructed wetland system was constructed at the Research Center for EcoEnvironmental Sciences (RCEES), Chinese Academy of Sciences, Beijing, China, in November 2008 (Fig. 2).

Two parallel VFCWs were constructed using rectangular polyethylene containers, each one having a surface area of $0.75 \mathrm{~m}^{2}$ (length $\times$ width $\left.=1.5 \times 0.5 \mathrm{~m}\right)$ and a depth of $70 \mathrm{~cm}$ and containing a $50-\mathrm{cm}$ media layer and $20-\mathrm{cm}$ free water surface. The $50-\mathrm{cm}$ media layer consisted of two successive layers of the following media: a $15-\mathrm{cm}$ bottom layer of 6 - to $25-\mathrm{mm}$ diameter washed river gravel, which served as the drainage (bottom) layer, and a 35-cm-deep main layer of 4- to 8$\mathrm{mm}$ diameter 1:1 mixture (by weight) of zeolite and dolomite in one of the VFCWs (named as $\mathrm{CW}_{1}$ ) or the same zeolite in the other (named as $\mathrm{CW}_{2}$ ).

Two six-level, two-layer drop aeration devices with total drop height of $0.9 \mathrm{~m}$ were installed above each one of the VFCWs in December 2009 instead of the perforated inlet pipes in the first year.

The VFCWs were washed with tap water until the analysis of percolate confirmed that no constituents of concern (e.g., suspended solid, nitrogen, and phosphorus) were leached out and no any other differences were found among the parallel wetlands (Prochaska et al. 2007). Then, the wetlands were fed with domestic wastewater pretreated by an anaerobic reactor in order to avoid bed clogging, with each one receiving $144 \mathrm{~L} /$ day, being equal to a hydraulic loading rate (HLR) of approximately $0.192 \mathrm{~m}^{3} /\left(\mathrm{m}^{2}\right.$ day). However, from December 2010 to March 2011, the influent flow was $58 \mathrm{~L} /$ day in order to investigate the effect of the HLR on the nitrogen removal of $\mathrm{CW}_{1}$ and $\mathrm{CW}_{2}$.

The influent quality of the VFCWs is shown in Table 1.

\subsection{Sampling and Analyses}

With regard to the wastewater chemical analyses, water samples were collected in plastic bottles previously washed with deionized water and repeatedly rinsed with the sampling water. Samples were taken once every month at the inlet and outlets of both $\mathrm{CW}_{1}$ and $\mathrm{CW}_{2}$, except for the period from January 2010 to September 2010 during which samples were taken once every 2 months. Inlet water samples were collected on certain days before the outlet ones according to the estimated hydraulic retention time of each treatment unit. 
Fig. 2 Layout of the vertical flow constructed wetland system (the sizes of the figure are expressed in millimeters). 1 Six-level two-layer drop aeration device; 2 Sampling pipe; 3 A 1:1 mixture (by weight) of zeolite $\mathrm{d} 4-8 \mathrm{~mm}$ and dolomite d4-8 $\mathrm{mm}$ in $\mathrm{CW}_{1}$ (the same zeolite in $\mathrm{CW}_{2}$ ); 4 Gravel d6-25 mm; 5 Perforated drainage pipe; 6 U-pipe used to set the water level in VFCWs

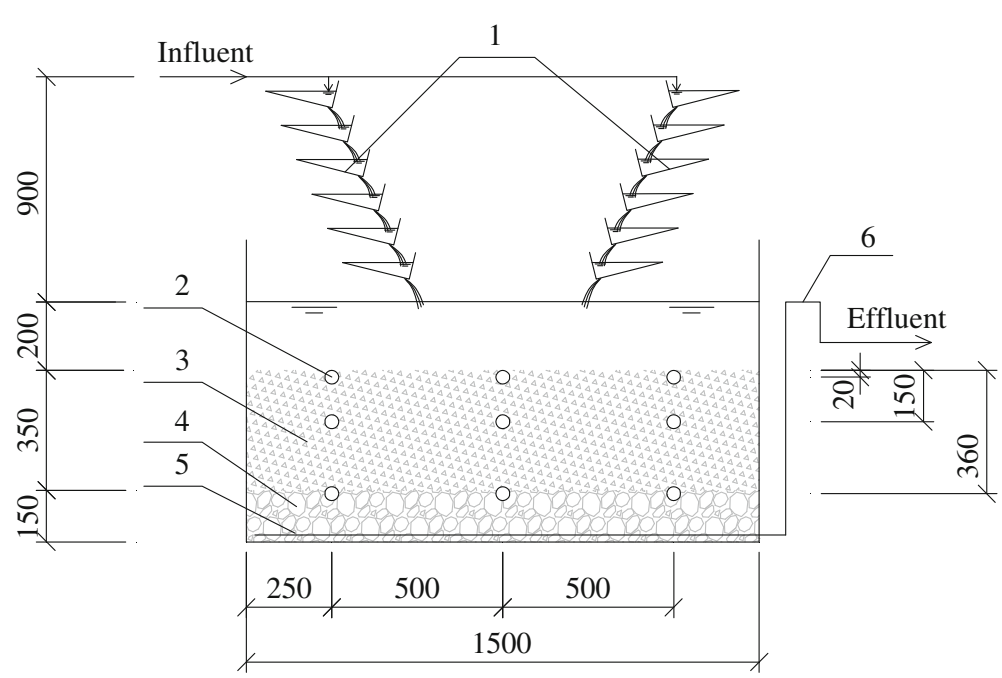

Samples at specified filter media depths $(20,150$, and $360 \mathrm{~mm}$ ) of the wetlands were also collected in different phases through a set of horizontal sampling pipes (shown in Fig. 2) equipped at about 20\%, 50\%, and $80 \%$ of the bed length. Besides, the filter media (zeolite and dolomite) were taken out from different depths of the VFCWs with a special sampler.

Temperature $(T)$, DO, and $\mathrm{pH}$ were regularly measured with a WTW-Multi 340i analysis instrument (made in Germany), and the probes were CellOx325 and SenTix 41-3 pH electrode, respectively. The 5day biochemical oxygen demand $\left(\mathrm{BOD}_{5}\right)$ was measured by Method 5210 A using a Hach BOD $_{5}$ Trak instrument, and the chemical oxygen demand (COD) was measured by Method 5220 D using the Hach COD Digestion Solution. Suspended solids (SS), ammonium nitrogen $\left(\mathrm{NH}_{4}{ }^{+}-\mathrm{N}\right)$, total nitrogen (TN), and total phosphate (TP) were analyzed according to the respective standard methods (CEPB 2004). The chemical compositions of the filter media were analyzed by X-ray fluorescence (Thermo Electron Corporation, ARLADVANT $\mathrm{XP}^{+}$, USA), and the nitrogen content was measured using techniques described in the literature (Bao 2000).

\section{Results and Discussion}

3.1 Oxygen Transfer Capability of the Multilevel, Two-Layer Drop Aeration Device

The oxygen transfer capabilities of the multilevel, two-layer drop aeration device and the direct drop aeration process were measured. The results showed that oxygen transferred into wastewater through the multilevel, two-layer drop aeration device was more effective and efficient than through the direct drop aeration process, supplying $2-6 \mathrm{mg} / \mathrm{L}$ higher DO per meter of drop height than the latter one (Fig. 3). The amount of oxygen transferred into wastewater increased with decreasing flow rate and increased quickly at the drop height below $1.2 \mathrm{~m}$, and then slowly with higher drop height. A similar tendency of reoxygenation increasing gradually smooth down with increasing waterfall height was obtained by $\mathrm{Li}$ et al. (2008); DO increased to $6.0 \mathrm{mg} / \mathrm{L}$ through direct waterfall of $1.6 \mathrm{~m}$ at a flow rate of $300 \mathrm{~mL} / \mathrm{min}$ at the experimental temperature of $16^{\circ} \mathrm{C}$. Zheng (2006) found that DO in the influent of the three-level upland constructed wetland were $6.59,5.60$, and $5.27 \mathrm{mg} / \mathrm{L}$

Table 1 Influent quality of the VFCWs

\begin{tabular}{llllllll}
\hline Parameters & $\mathrm{pH}$ & $\mathrm{SS}(\mathrm{mg} / \mathrm{L})$ & $\mathrm{COD}(\mathrm{mg} / \mathrm{L})$ & $\mathrm{BOD}_{5}(\mathrm{mg} / \mathrm{L})$ & $\mathrm{NH}_{4}^{+}-\mathrm{N}(\mathrm{mg} / \mathrm{L})$ & $\mathrm{TN}(\mathrm{mg} / \mathrm{L})$ & $\mathrm{TP}(\mathrm{mg} / \mathrm{L})$ \\
\hline Mean & 7.7 & 41 & 164 & 69 & 61.6 & 70.5 & 5.0 \\
Range & $7.5-8.0$ & $14-138$ & $36-462$ & $25-240$ & $35.1-114.7$ & $39.2-126.1$ & $1.0-9.8$ \\
\hline
\end{tabular}


through a waterfall of $2.8,2.2$, and $1.7 \mathrm{~m}$, respectively. In this study, DO in the wastewater increased to 9.60 $10.04 \mathrm{mg} / \mathrm{L}$ through the multilevel, two-layer aeration device at $1.8-\mathrm{m}$ drop aeration height and a flow rate of $100-300 \mathrm{~mL} / \mathrm{min}$.

Oxygen deficiency of wastewater had a relationship with the drop height, as shown in Fig. 4, in accordance with the following equation ( $\mathrm{Li}$ et al. 2008):

$\ln \left(\mathrm{DO}_{s a}-C_{t}\right)=a-b H^{1 / 2}$

where $\mathrm{DO}_{\mathrm{sa}}$ is the saturated dissolved oxygen concentration at the experimental temperature $\left(\mathrm{DO}_{\mathrm{sa}}\right.$ is $10.77 \mathrm{mg} / \mathrm{L}$ at $\left.12^{\circ} \mathrm{C}\right), C_{t}$ is the dissolved oxygen concentration of wastewater after dropping at the experimental temperature, $H$ is the drop height, and $a$ and $b$ are the reoxygenation constant parameters.

For the above experimental data, $a, b$, and $r^{2}$ (correlation coefficient) are shown in Table 2. The parameter $b$ for the multilevel, two-layer drop aeration device was twice that for the direct drop aeration process, which indicated that the reoxygenation capacity of the multilevel, two-layer drop aeration device was much higher than that of the direct drop aeration process, which was ascribed to the capability of the former transferring more oxygen into wastewater during the multilevel two-layer trip. The trip was shown in Fig. 1: the wastewater flowed from the right on the free water surface of the top two-layer drop aeration unit to the left where it turned and then flowed toward to the opposite direction below the inclined two-layer drop aeration unit, and finally dropped into the next one by gravity. Therefore, compared with the direct drop aeration process, the multilevel, two-layer drop aeration device efficiently supplied $2-6 \mathrm{mg} / \mathrm{L}$ higher DO per meter of drop height into the wastewater, with advantages of no energy consumption, high oxygen transfer capacity, no clogging, and may produce low odor.

\subsection{Organics Removal Efficiency of the VFCWs Before and After Installation of the Six-Level, Two-Layer Drop Aeration Devices}

Before and after installation of the six-level, two-layer drop aeration devices (from January 2009 to November 2009 and from January 2010 to November 2010), the average concentration of $\mathrm{COD}$ and $\mathrm{BOD}_{5}$ in the influent and effluent and the removal efficiencies of $\mathrm{CW}_{1}$ and $\mathrm{CW}_{2}$ are shown in Figs. 5 and 6 , respectively.

It was known that organics removal loads of the VFCWs increased substantially after installation of the six-level, two-layer drop aeration devices, with average $\mathrm{BOD}_{5}$ removal load increasing from 8.1 to $14.2 \mathrm{gm}^{-2}$ day $^{-1}$ for $\mathrm{CW}_{1}$ and from 9.1 to $13.6 \mathrm{~g}$ $\mathrm{m}^{-2}$ day $^{-1}$ for $\mathrm{CW}_{2}$, which indicated that the multilevel, two-layer drop aeration devices are superior to the direct drop aeration ones, with much higher pollutant removal loads of the VFCWs.

After installation of the six-level, two-layer drop aeration devices, the average $\mathrm{BOD}_{5}$ removal efficien-
Fig. 3 Oxygen transfer capability through the multilevel, two-layer drop aeration device (shown as $M-1^{\#}, M-2^{\#}$, and $\left.M-3^{\#}\right)$ compared with the conventional direct drop aeration process (shown as $D-1^{\#}, D-2^{\#}$, and $\left.D-3^{\#}\right)$ at the experimental temperature of $12^{\circ} \mathrm{C}$

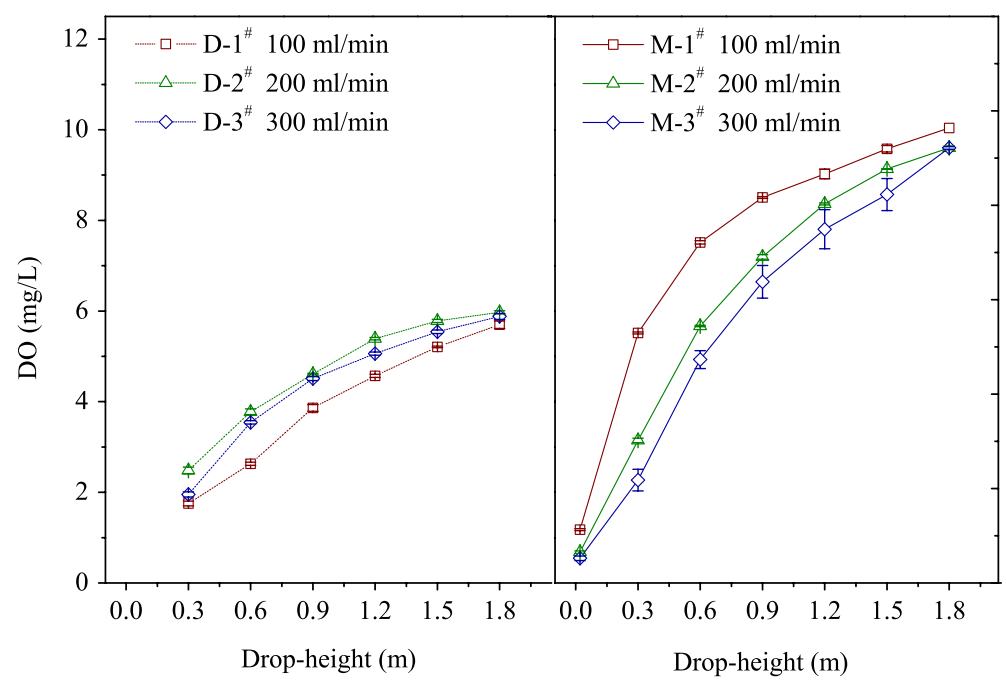


Fig. 4 Correlation between oxygen deficiency of wastewater and drop height through the direct drop aeration process (shown as $D$ $1^{\#}, D-2^{\#}$, and $\left.D-3^{\#}\right)$ and the multilevel, two-layer drop aeration device (shown as $M-1^{\#}, M-2^{\#}$, and $\left.M-3^{\#}\right)$

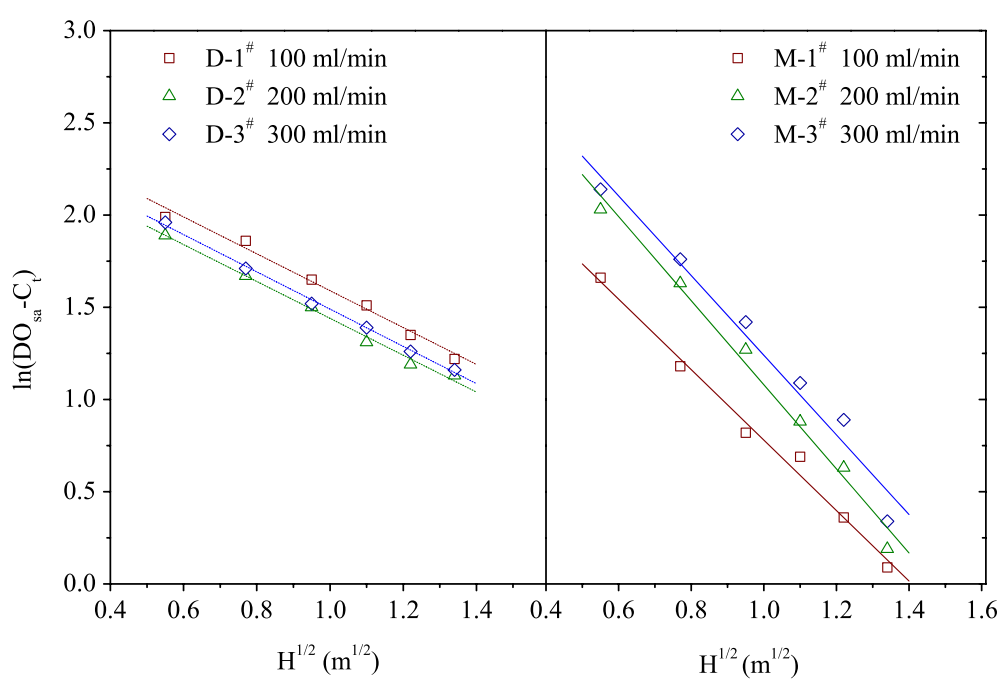

cy was as high as $93 \%$ and $90 \%$ by $\mathrm{CW}_{1}$ and $\mathrm{CW}_{2}$, respectively, at the average organic loading rate of $0.016 \mathrm{~kg} \mathrm{BOD} \mathrm{m}^{-2} \mathrm{day}^{-1}$ and high HLR of $0.192 \mathrm{~m}^{3} \mathrm{~m}^{-2}$ day $^{-1}$. The HLR is twice or triple that in other studies. For example, Zhang et al. (2010) adopted artificial aeration which consumed $0.077 \mathrm{~kW} \mathrm{~h} / \mathrm{m}^{3}$ electric energy to improve pollutant removal by horizontal subsurface constructed wetland for domestic wastewater treatment, and the removal efficiency of $\mathrm{BOD}_{5}$ was $94.4 \%\left(16.7 \mathrm{gBOD}_{5}\right.$ $\mathrm{m}^{-2}$ day $^{-1}$ ) at the average organic loading rate of $0.018 \mathrm{~kg} \mathrm{BOD} \mathrm{m}^{-2} \mathrm{day}^{-1}$ and a HLR of $0.062 \mathrm{~m}^{3} \mathrm{~m}^{-2} \mathrm{day}^{-1}$. Herrera Melián et al. (2010) obtained average removals of $86 \%$ for BOD and $80 \%$ for COD using a hybrid constructed wetland (VF+ HF) with a HLR of $0.037-0.079 \mathrm{~m}^{3} \mathrm{~m}^{-2}$ day $^{-1}$ and organic loading rate of $0.006-0.023 \mathrm{~kg} \mathrm{BOD}_{5}$ $\mathrm{m}^{-2}$ day $^{-1}$ for domestic wastewater treatment.

Table 2 Parameters of the direct drop aeration process (D-1 at $100 \mathrm{~mL} / \mathrm{min}, \mathrm{D}-2$ at $200 \mathrm{~mL} / \mathrm{min}$, and D-3 at $300 \mathrm{~mL} / \mathrm{min}$ ) and the multilevel two-layer drop aeration device (M-1 at $100 \mathrm{~mL} /$ $\mathrm{min}, \mathrm{M}-2$ at $200 \mathrm{~mL} / \mathrm{min}$, and $\mathrm{M}-3$ at $300 \mathrm{~mL} / \mathrm{min}$ )

\begin{tabular}{lllllll}
\hline Parameters & D-1 & D-2 & D-3 & M-1 & M-2 & M-3 \\
\hline$a$ & 2.59 & 2.44 & 2.50 & 2.69 & 3.36 & 3.40 \\
$b$ & 1.00 & 1.00 & 1.01 & 1.91 & 2.28 & 2.16 \\
$r^{2}$ & 0.987 & 0.994 & 0.998 & 0.989 & 0.987 & 0.972 \\
\hline
\end{tabular}

\subsection{Nitrogen Removal by the VFCWs in Different Operational Phases}

The $\mathrm{NH}_{4}{ }^{+}-\mathrm{N}$ and $\mathrm{TN}$ removal by $\mathrm{CW}_{1}$ and $\mathrm{CW}_{2}$ in different operational phases (phase 1 from January 2009 to November 2009; phase 2 from January 2010 to November 2010; phase 3 from December 2010 to March 2011) is shown in Figs. 7 and 8, respectively.

The nitrogen removal efficiency decreased significantly with time in phase 1 because of the gradual saturation of zeolite filled in the wetlands with ammonium. The $\mathrm{NH}_{4}{ }^{+}-\mathrm{N}$ removal efficiency of $\mathrm{CW}_{2}$ was $5-36 \%$ higher than that of $\mathrm{CW}_{1}$ because of the fact that the amount of zeolite filled in $\mathrm{CW}_{2}$ was twice that in $\mathrm{CW}_{1}$ and the maximum ammonium adsorption capacity of zeolite was $8.1 \mathrm{mg} \mathrm{NH}_{4}{ }^{+}-\mathrm{N} / \mathrm{g}$, while that of dolomite filled in $\mathrm{CW}_{1}$ was almost nearly zero. It suggested that zeolite was superior to dolomite in the improvement of nitrogen removal in the first year of operation of VFCWs.

In phase 2, when zeolite had been saturated with ammonium, nitrogen removal did not decrease with time anymore but remained relatively stable. Thus, it was known that in the second year after zeolite saturation with ammonium, nitrogen removal did not rely on ammonium adsorption on zeolite anymore.

In phase 3, when the HLR of the wetlands was reduced to near half, $0.077 \mathrm{~m}^{3} /\left(\mathrm{m}^{2}\right.$ day $)$, nitrogen removal increased obviously, with average values of $42 \% \mathrm{NH}_{4}{ }^{+}-\mathrm{N}$ and $37 \%$ TN by $\mathrm{CW}_{1}$ in phase 3 
Fig. 5 COD removal of $\mathrm{CW}_{1}$ and $\mathrm{CW}_{2}$ before and after installation of the sixlevel, two-layer drop aeration devices

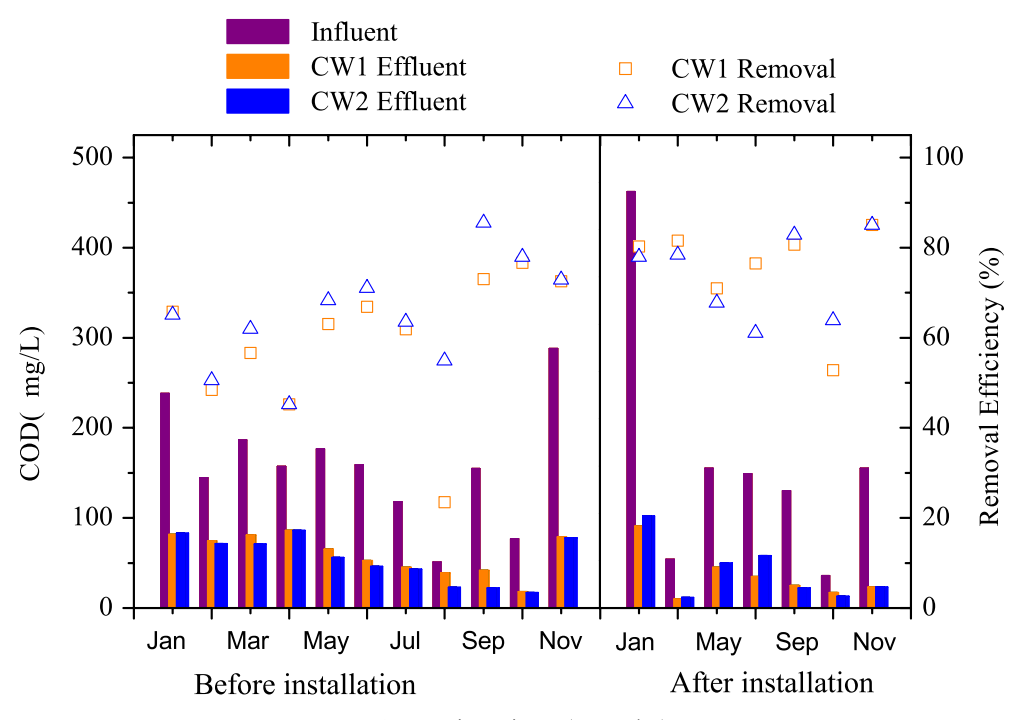

Operation time (months) compared with $9 \% \mathrm{NH}_{4}{ }^{+}-\mathrm{N}$ and $15 \% \mathrm{TN}$ in phase 2 , which indicated that the HLR of the wetlands had a significant impact on nitrogen removal. In practice, nitrogen removal is highly dependent on pollution loading rates (Tanner 2001). In addition, unlike in phase 1 , phase 3 nitrogen removal by $\mathrm{CW}_{1}$ was $8 \%$ higher than that by $\mathrm{CW}_{2}$.

The chemical compositions and the nitrogen content of zeolite at different depths of $\mathrm{CW}_{1}$ and
$\mathrm{CW}_{2}$ are shown in Table 3. Compared with the initial zeolite, the nitrogen content of zeolite in the wetlands increased significantly. The nitrogen content of zeolite in $\mathrm{CW}_{1}$ was less than that in $\mathrm{CW}_{2}$ and was less on the top of the wetlands compared with that in the middle part. The amounts of $\mathrm{CaO}$ and $\mathrm{MgO}$ of zeolite in $\mathrm{CW}_{1}$ were higher than that in $\mathrm{CW}_{2}$ and were higher on the top of the wetlands than in the middle part, which is due to the effect of dolomite $\left(\mathrm{CaMg}\left(\mathrm{CO}_{3}\right)_{2}\right)$ filled in
Fig. $6 \mathrm{BOD}_{5}$ removal of $\mathrm{CW}_{1}$ and $\mathrm{CW}_{2}$ before and after installation of the sixlevel, two-layer drop aeration devices

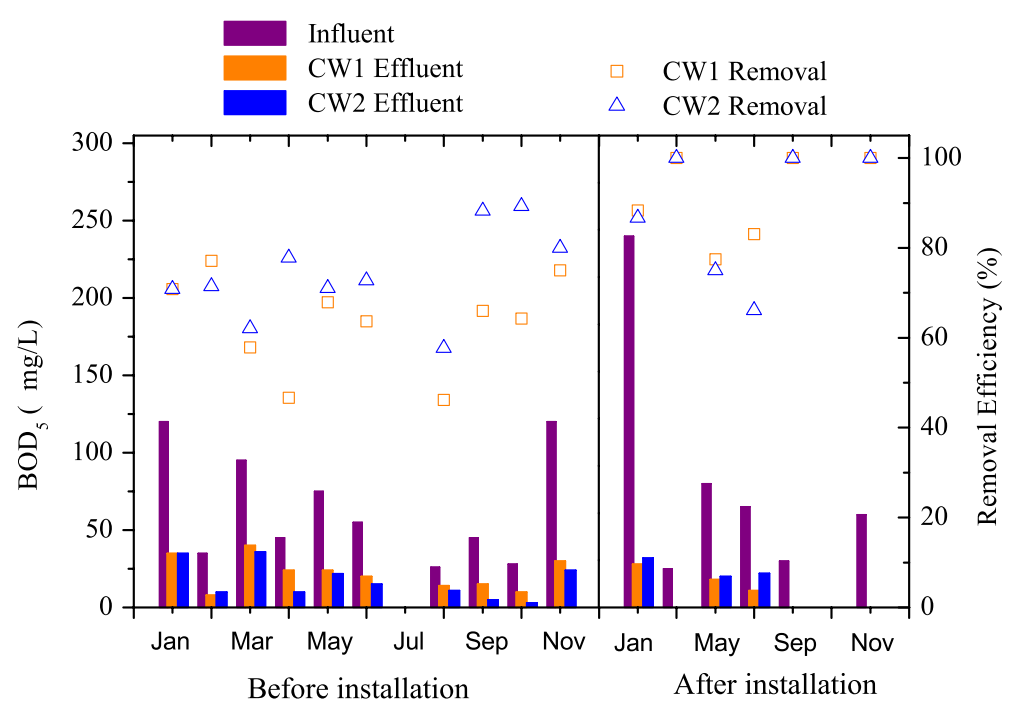

Operation time (months) 
Fig. $7 \mathrm{NH}_{4}^{+}-\mathrm{N}$ removal of $\mathrm{CW}_{1}$ and $\mathrm{CW}_{2}$ in different operational phases
Influent

CW1 Effluent

CW2 Effluent

CW1 Removal

$\triangle \quad$ CW2 Removal

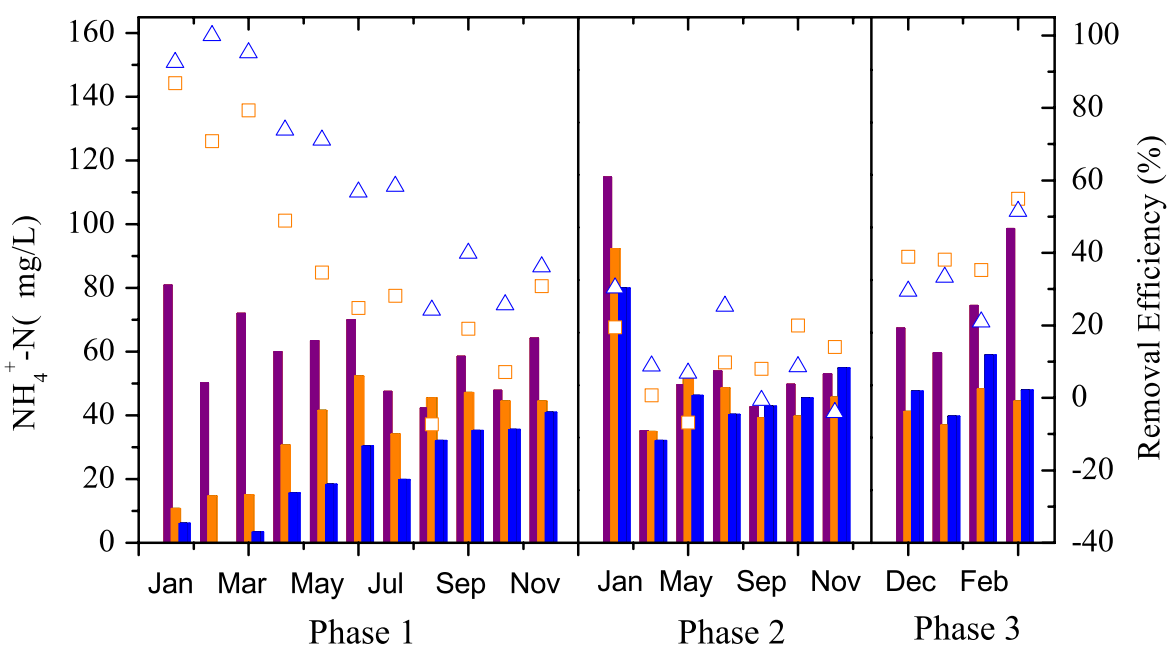

Operation time (months)
$\mathrm{CW}_{1}$. The cations such as $\mathrm{Ca}^{2+}$ and $\mathrm{Mg}^{2+}$ promoted the desorption of ammonium from zeolite through ion exchange (Wang et al. 2007). Nitrogen removal by the wetlands in a long operational time was mainly through bacterial transformations involving a sequential process of ammonification, nitrification, and denitrification (Babatunde et al. 2008).
3.4 Pollutant Distribution Along the Depths of the VFCWs in Different Operational Phases

The COD, $\mathrm{NH}_{4}{ }^{+}-\mathrm{N}$, and $\mathrm{TN}$ distribution along the depths of the VFCWs in different phases is shown in Figs. 9, 10, and 11, respectively. Waterfall was the sample after the six-level, two-layer drop aeration
Fig. $8 \mathrm{TN}$ removal of $\mathrm{CW}_{1}$ and $\mathrm{CW}_{2}$ in different operational phases

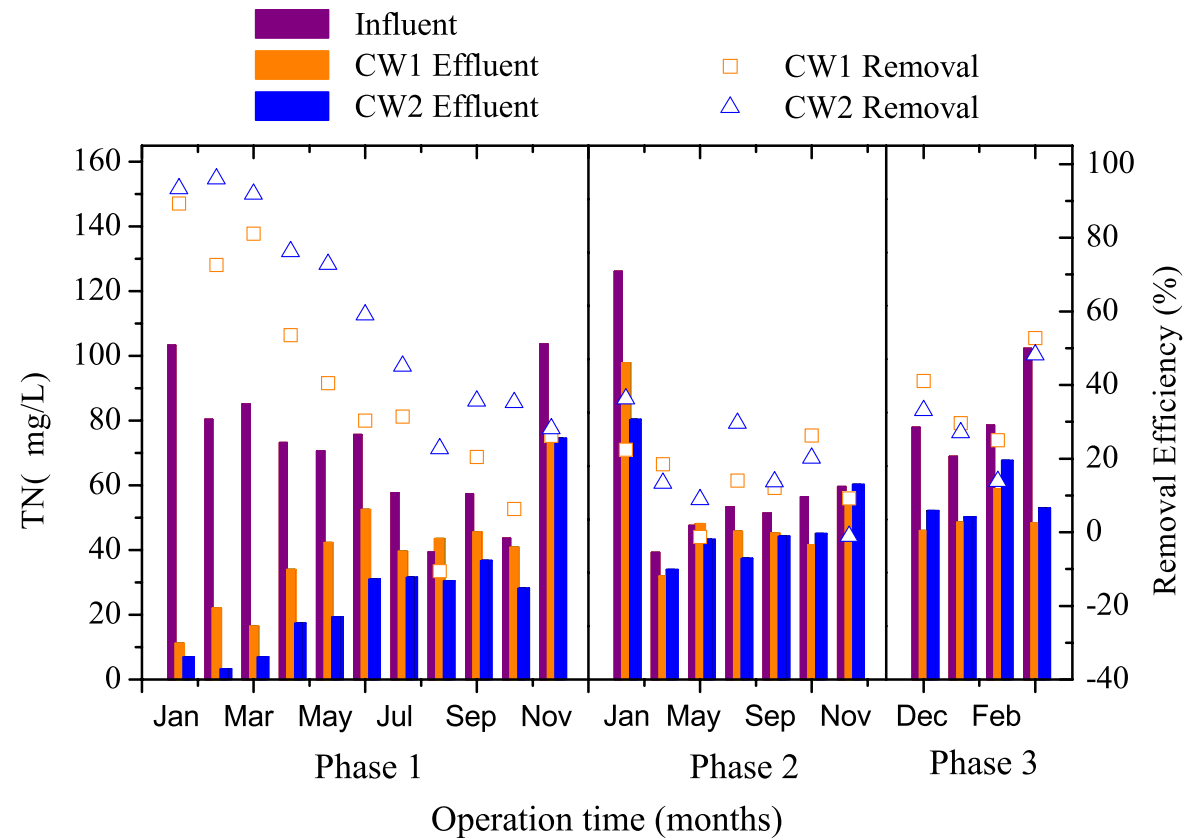


Table 3 Chemical compositions of zeolite at different depths of $\mathrm{CW}_{1}$ and $\mathrm{CW}_{2}$ in phase 3

\begin{tabular}{lllllllll}
\hline Component (\%) & $\mathrm{SiO}_{2}$ & $\mathrm{Al}_{2} \mathrm{O}_{3}$ & $\mathrm{~K}_{2} \mathrm{O}$ & $\mathrm{Fe}_{2} \mathrm{O}_{3}$ & $\mathrm{Na}_{2} \mathrm{O}$ & $\mathrm{CaO}$ & $\mathrm{MgO}$ & Nitrogen \\
\hline Initial zeolite & 65.45 & 11.78 & 6.94 & 2.48 & 0.613 & 3.48 & 0.47 & 0.003 \\
$\mathrm{CW}_{1}$ - top & 63.89 & 14.51 & 3.49 & 1.21 & 1.20 & 3.22 & 1.88 & 0.170 \\
$\mathrm{CW}_{1}$-mid & 65.88 & 15.35 & 4.50 & 1.28 & 1.23 & 2.11 & 1.40 & 0.181 \\
$\mathrm{CW}_{2}$ - top & 67.73 & 15.46 & 4.16 & 1.27 & 1.88 & 1.12 & 0.94 & 0.266 \\
$\mathrm{CW}_{2}$-mid & 67.85 & 15.53 & 4.12 & 1.21 & 2.36 & 1.02 & 0.86 & 0.325 \\
\hline
\end{tabular}

devices and was not analyzed in phase 1 because the drop aeration devices were not installed yet.

It was evident that the COD distribution along the depths of the $\mathrm{CW}_{1}$ and $\mathrm{CW}_{2}$ was similar in different phases and that its removal mainly took place in the upper $15-\mathrm{cm}$ filter layer, which suggested that organics were removed by the filtration of suspended organic substances and rapid microbial biodegradation of soluble ones in the upper part of the VFCWs, which was consistent with the conclusions of Tietz et al. and Zhou et al. Tietz et al. (2007) studied the characterization of microbial biocoenosis in VFCWs, which revealed high values (about 95\%) for microbial biomass in the top $10 \mathrm{~cm}$ of the filter due to the high nutrient content and adequate oxygen supply. Zhou et al. (2009) studied the microbial spatial distribution of VFCW, which showed that the amount of bacterial biomass in the surface layer was significantly higher than that in the subsurface layers.

Unlike the COD distribution, the $\mathrm{NH}_{4}{ }^{+}-\mathrm{N}$ and $\mathrm{TN}$ distributions along the depths of the wetlands were greatly different in different phases. Nitrogen concentration decreased gradually along the $35-\mathrm{cm}$ filter media layer of the VFCWs in phase 1 when nitrogen removal was mainly through the adsorption of zeolite. But in phase 2, when zeolite was saturated with ammonium, nitrogen concentration decreased only in the top 2-cm filter media layer and then did not decrease anymore along the depths from $2 \mathrm{~cm}$ to the bottom. It was suggested that after zeolite saturation with ammonium, nitrogen removal was limited at a high HLR as the amount of dissolved oxygen was insufficient to convert all ammonia in the VFCWs. However, in phase 3, nitrogen concentration decreased along the $15-\mathrm{cm}$ filter layer of the VFCWs since HLR was reduced to near half, $0.077 \mathrm{~m}^{3} /\left(\mathrm{m}^{2}\right.$ day $)$, leading to a relatively adequate oxygen supply.

In addition, the novel vertical flow constructed wetlands with the six-level, two-layer drop aeration devices had high pollutant removal efficiencies of $91 \% \mathrm{BOD}_{5}, 80 \% \mathrm{COD}$, and $84 \% \mathrm{SS}$ at a high HLR of $0.192 \mathrm{~m}^{3} /\left(\mathrm{m}^{2}\right.$ day $)$, and the average effluent concentrations were $6 \mathrm{mg} / \mathrm{L} \mathrm{BOD}{ }_{5}, 32 \mathrm{mg} / \mathrm{L} \mathrm{COD}$, and $9 \mathrm{mg} / \mathrm{L} \mathrm{SS}$, respectively, which were all less than the values required in the standard of class 1A (GB 18918-2002: Discharge standard of pollutants for municipal wastewater treatment plant). However, the phosphate removal efficiency was $<20 \%$; a possible solution may be the application of chemical precipitation methods for further phosphate removal. Therefore, the effluent should not be discharged into the receiving waters where the
Phase 1

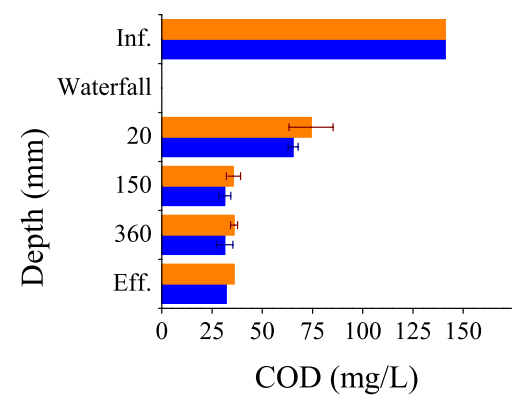

Phase 2

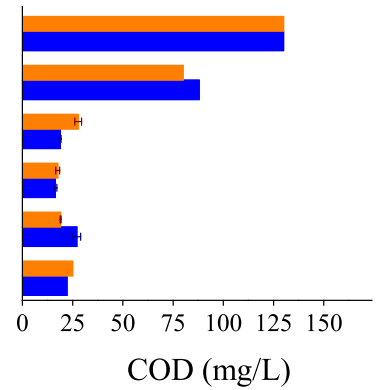

Phase 3

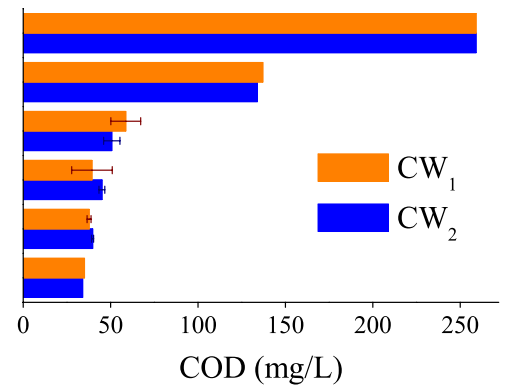

Fig. $9 \mathrm{COD}$ distribution along the depths of $\mathrm{CW}_{1}$ and $\mathrm{CW}_{2}$ in different operational phases 

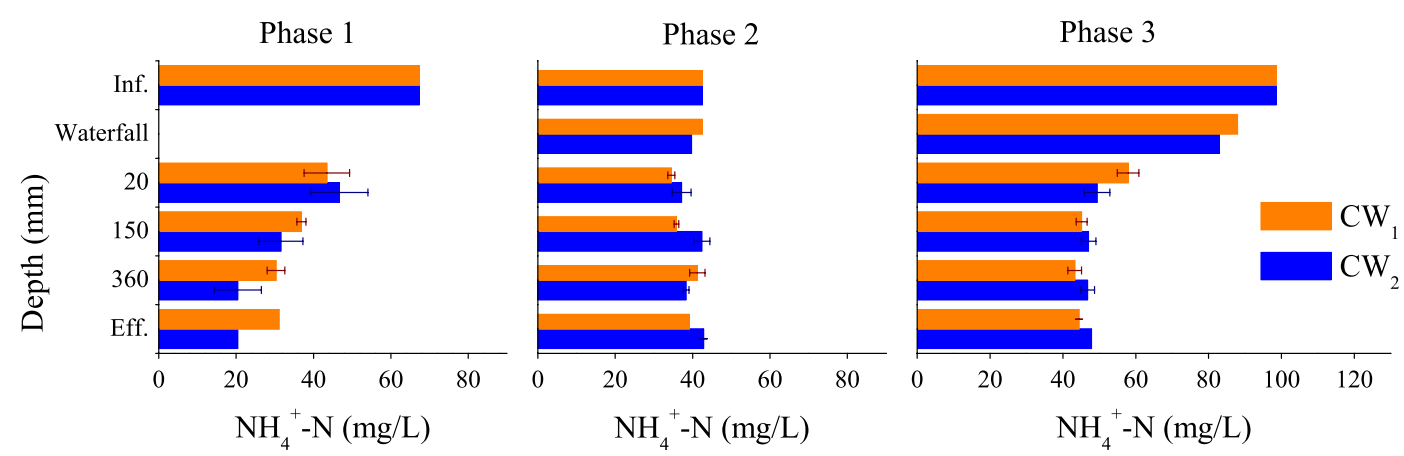

Fig. $10 \mathrm{NH}_{4}{ }^{+}-\mathrm{N}$ distribution along the depths of $\mathrm{CW}_{1}$ and $\mathrm{CW}_{2}$ in different operational phases

aquatic environment is sensitive to nutrients, in particular when phosphorus is the limiting nutrient. In that case, the effluent should preferably be used for agricultural irrigation.

\section{Conclusions}

The vertical flow constructed wetland system with multilevel, two-layer drop aeration is an appropriate alternative for rural wastewater treatment especially in mountain areas, with numerous advantages of low capital and operation costs, no energy consumption, easy maintenance, high hydraulic loading rate, high pollutant removal efficiency, and no clogging.

Compared with the direct drop aeration process, oxygen transferred into the wastewater through the multilevel, two-layer drop aeration device was improved by $2-6 \mathrm{mg} / \mathrm{L}$ DO per meter of drop height. As a result, several six-level, two-layer drop aeration devices of total $0.9-\mathrm{m}$ drop height were installed above the VFCWs, and the operation performance results showed that they were superior to the direct drop aeration process for improving pollutant removal, with $\mathrm{BOD}_{5}$ removal load increasing from 8.1 to $14.2 \mathrm{gm}^{-2}$ day $^{-1}$ for $\mathrm{CW}_{1}$.

With regard to the different filter media, zeolite improved nitrogen removal in the first year, with 5$36 \%$ higher $\mathrm{NH}_{4}{ }^{+}-\mathrm{N}$ removal efficiency of $\mathrm{CW}_{2}$ compared with that in $\mathrm{CW}_{1}$. Zeolite has the function of removing ammonia in the first year while giving time for the biology to develop a nitrification activity. Since it does not have a significant positive effect on phosphate removal, dolomite does not have a function and can be replaced by zeolite.

The pollutant distribution along the depths of the VFCWs showed that COD was mainly removed by the filtration of suspended organic substances and rapid microbial biodegradation of soluble ones in the upper $15-\mathrm{cm}$ filter layer in all operational phases. However, nitrogen removal mainly occurred through adsorption in the upper $35-\mathrm{cm}$ zeolite layer in phase 1 (in the first year), while after zeolite saturation with ammonium, nitrogen removal mainly took place in the upper $15-\mathrm{cm}$ filter layer of the wetlands (phase 3 at a lower HLR of $0.077 \mathrm{~m}^{3} /\left(\mathrm{m}^{2}\right.$ day $\left.)\right)$.
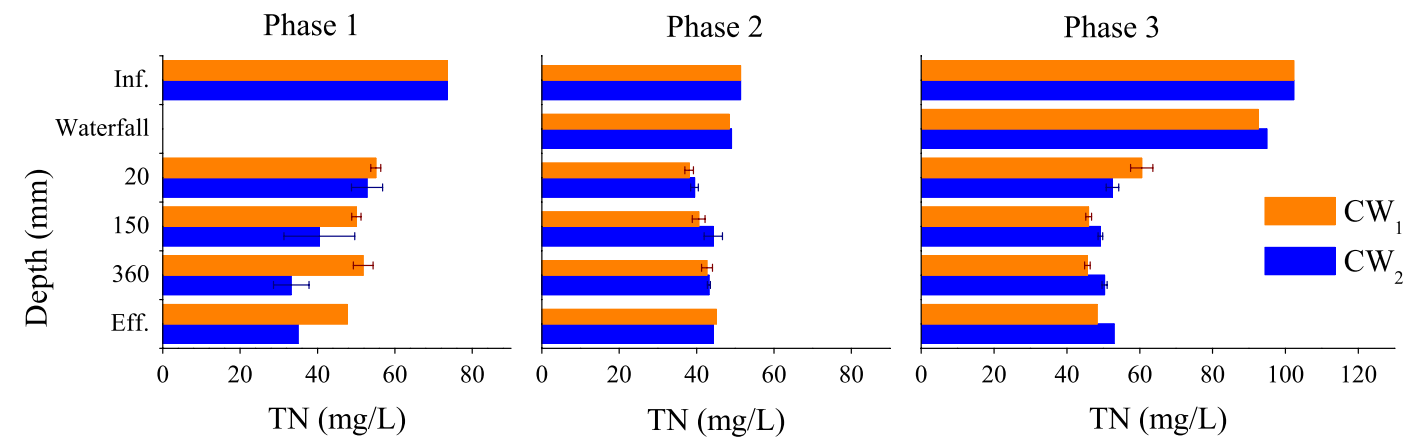

Fig. $11 \mathrm{TN}$ distribution along the depths of $\mathrm{CW}_{1}$ and $\mathrm{CW}_{2}$ in different operational phases 
Acknowledgments This work was supported by Major Science and Technology Program for Water Pollution Control and Treatment (2008ZX07101-006-3) and Knowledge Innovation Project of Chinese Academy of Sciences of young talents (no. RCEES-QN-2007xx).

\section{References}

Arroyo, P., Ansola, G., \& Luis, E. (2010). Effectiveness of a full-scale constructed wetland for the removal of metals from domestic wastewater. Water, Air, and Soil Pollution, 210, 473-481.

Austin, D. C., Lohan, E., \& Verson, E. (2003). Proceedings of the Water Environment Technical Conference 2003, Los Angeles, California.

Babatunde, A. O., Zhao, Y. Q., O'neill, M., \& O'sullivan, B. (2008). Constructed wetlands for environmental pollution control: A review of developments, research and practice in Ireland. Environment International, 34(1), 116-126.

Bao, S. (2000). Chemical analysis for agricultural soil (2nd ed.). Beijing: China Agriculture Press.

Behrends, L., Sikora, F., Coonrod, H., Bailey, E., \& Bulls, M. (1996). Proceedings of WEFTEC '96; The 69th Annual Conference and Exposition of the Water Environment Federation, Alexandria, Virginia.

Brix, H., \& Arias, C. A. (2005). The use of vertical flow constructed wetlands for on-site treatment of domestic wastewater: New Danish guidelines. Ecological Engineering, 25(5), 491-500.

Cameron, K., Madramootoo, C., Crolla, A., \& Kinsley, C. (2003). Pollutant removal from municipal sewage lagoon effluents with a free-surface wetland. Water Research, 37 (12), 2803-2812.

CEPB (China Environmental Protection Bureau). (2004). Standard methods for examination of water and wastewater (4th ed.). China: Chinese Environmental Science Press.

Coleman, J., Hench, K., Garbutt, K., Sexstone, A., Bissonnette, G., \& Skousen, J. (2001). Treatment of domestic wastewater by three plant species in constructed wetlands. Water, Air, and Soil Pollution, 128, 283-295.

Cooper, P. (2009). What can we learn from old wetlands? Lessons that have been learned and some that may have been forgotten over the past 20 years. Desalination, 246 (1-3), 11-26.

Dufay, J. A. (2000). Constructed wetlands remediation system. New Mexico Patent 6,159,371.

Flowers, D. A. (2002). Process and system for enhanced nitrogen removal in a wetland wastewater treatment facility. United States Patent 6,447,682.

Green, M., Friedler, E., \& Safrai, I. (1998). Enhancing nitrification in vertical flow constructed wetland utilizing a passive air pump. Water Research, 32(12), 35133520 .

Herrera Melián, J. A., Martín Rodríguez, A. J., Arana, J., González Díaz, O., \& González Henríquez, J. J. (2010). Hybrid constructed wetlands for wastewater treatment and reuse in the Canary Islands. Ecological Engineering, 36 (7), 891-899.
Hua, G. F., Zhu, W., Zhao, L. F., \& Huang, J. Y. (2010). Clogging pattern in vertical-flow constructed wetlands: Insight from a laboratory study. Journal of Hazardous Materials, 180(1-3), 668-674.

Joan, G., Rousseau, D., Caselles, O. A., Story, A., Pauw, N., \& Vanrolleghem, P. (2007). Impact of prior physico-chemical treatment on the clogging process of subsurface flow constructed wetlands: Model-based evaluation. Water, Air, and Soil Pollution, 185, 101-109.

Li, J., Zhong, C., \& Deng, C. (2008). Study on relationship among waterfall aeration height, flux and reoxygenation content. Environmental Science (China), 34(5), 3941 .

Liang, H., Gao, M., Liu, J., Wei, Y., \& Guo, X. (2010). A novel integrated step-feed biofilm process for the treatment of decentralized domestic wastewater in rural areas of China. Journal of Environmental Sciences, 22 (3), 321-327.

Liu, J., Zou, J., \& Guo, X. (2010). Multi-level two-layer returning water-spreading drop oxygenating method and device. State Intellectual Property Office of the P. R. C. Patent 200910244241.

Luederitz, V., Eckert, E., Lange-Weber, M., Lange, A., \& Gersberg, R. M. (2001). Nutrient removal efficiency and resource economics of vertical flow and horizontal flow constructed wetlands. Ecological Engineering, 18(2), 157171.

Martin, I., Betancort, J. R., \& Pidre, J. R. (2007). Contribution of non-conventional technologies for sewage treatment to improve the quality of bathing waters (ICREW project). Desalination, 215(1-3), 82-89.

MHURDPRC. (2005). Present situation and problems of rural human settlements. Beijing: Ministry of Housing and Urban-Rural Development of the People's Republic of China.

Prochaska, C. A., Zouboulis, A. I., \& Eskridge, K. M. (2007). Performance of pilot-scale vertical-flow constructed wetlands, as affected by season, substrate, hydraulic load and frequency of application of simulated urban sewage. Ecological Engineering, 31 (1), 57-66.

Steer, D., Fraser, L., Boddy, J., \& Seibert, B. (2002). Efficiency of small constructed wetlands for subsurface treatment of single-family domestic effluent. Ecological Engineering, 18(4), 429-440.

Tanner, C. C. (2001). Plants as ecosystem engineers in subsurface flow treatment wetlands. Water Science and Technology, 44, 9-17.

Tietz, A., Kirschner, A., Langergraber, G., Sleytr, K., \& Haberl, R. (2007). Characterisation of microbial biocoenosis in vertical subsurface flow constructed wetlands. Science of the Total Environment, 380(1-3), 163-172.

Wallace, S. D., Parkin, G. F., \& Cross, C. S. (2001). Cold climate wetlands: Design and performance. Water Science and Technology, 44(11/12), 259-266.

Wang, Y. F., Lin, F., \& Pang, W. Q. (2007). Ammonium exchange in aqueous solution using Chinese natural clinoptilolite and modified zeolite. Journal of Hazardous Materials, 142(1-2), 160-164.

Zhang, L., Zhang, L., Liu, Y., Shen, Y., Liu, H., \& Xiong, Y. (2010). Effect of limited artificial aeration on constructed 
wetland treatment of domestic wastewater. Desalination, 250(3), 915-920.

Zhao, L., Zhu, W., \& Tong, W. (2009). Clogging processes caused by biofilm growth and organic particle accumulation in lab-scale vertical flow constructed wetlands. Journal of Environmental Sciences, 21(6), 750-757.
Zheng, J. (2006). Study on upland constructed wetland. Chongqing: Chongqing University.

Zhou, Q., He, F., Zhang, L., Wang, Y., \& Wu, Z. (2009). Characteristics of the microbial communities in the integrated vertical-flow constructed wetlands. Journal of Environmental Sciences, 21(9), 1261-1267. 